\title{
Errata
}

The Publisher

Published online: 17 July 2008

(C) Springer Science + Business Media, LLC 2008

An erratum is issued to the articles mentioned below because of incorrect Copyright Line. It should read "Springer Science + Business Media, LLC" instead of "Springer Science + Business Media B.V."

\section{Reinterpreting between-group inequality}

\section{Chris Elbers • Peter Lanjouw • Johan A. Mistiaen • Berk Özler}

Received: 7 April 2006 / Accepted: 4 May 2007

(C) Springer Science + Business Media, LLC 2007

\section{Erratum to: Journal of Economic Inequality} DOI 10.1007/s10888-007-9064-x

\section{Discrete choice models of labour supply, behavioural microsimulation} and the Spanish tax reforms

\section{José M. Labeaga · Xisco Oliver · Amedeo Spadaro}

Received: 7 September 2005 / Accepted: 22 February 2007

(C) Springer Science + Business Media, LLC 2007

Erratum to: Journal of Economic Inequality

DOI 10.1007/s10888-007-9057-9

The online versions of the original articles can be found under doi: 10.1007/s10888-007-9064-x and doi: $10.1007 / \mathrm{s} 10888-007-9057-9$. 